\title{
ENDÜLÜS MÜSLÜMANLARININ İSPANYA'DAN SÜRGÜNÜNÜN OSMANLI COĞRAFYASI VE EKONOMİSİ ÜZERİNDEKİ ETKİLERİ: KUZEY AFRİKA ÖRNEĞİ
}

\section{THE EFFECTS OF THE ANDALUSIAN MUSLIMS' EXILE FROM SPAIN ON THE OTTOMAN GEOGRAPHY AND ECONOMY: NORTH AFRICAN EXAMPLE}

Faruk BAL * $\ddot{O}$

İspanyol Yahudilerinin İspanya'dan sürgünü, İstanbul, Selanik ve İzmir gibi Osmanl topraklarına iskânları ile İmparatorluk coğrafyasındaki etkileri üzerine çok sayıda çalışma yapılmasına ră̆men Endülüs Müslümanlarının göçünün sosyal ve ekonomik sonuçlarına temas eden çalışmalar sınırlı sayıda kalmıştır. 1492'de İberya Yarımadası'ndaki son Müslüman şehri Gırnata'nın İspanyol Krallı̆̆ı'na teslim olmasından itibaren başlayan büyük göç dalgaları, 1609 yılında Yarımada'da kalan Müslümanların tamamının sürgün kararı alınmasıyla birlikte 1609-1614 tarihleri arasında en yoğun dönemini yaşamıştır. Sürgün edilen Müslümanların yerleştiği

Anahtar Kelimeler Osmanlı Devleti, Kuzey Afrika, Endülüs Müslümanlarının sürgünü, Osmanlıya göç, İspanya

Keywords Ottoman Empire, North Africa, the Exile of Andalusian Muslims, Immigration to the Ottoman Empire,

Spain

* Doç. Dr., İstanbul Medeniyet Üniversitesi, Siyasal Bilgiler Fakültesi, İktisat Bölümü faruk.bal@medeniyet.edu.tr ORCID: 0000-0001-5167-7829 İstanbul/TÜRKIYE

Gönderim Tarihi: 12/04/2021 Kabul Tarihi: $26 / 08 / 2021$ yerlerin başında Osmanlı hâkimiyetindeki Kuzey Afrika topraklarn gelmekteydi. Bu sürgünün hem İspanyollar hem de Osmanlılar için önemli sonuçları olmuştur. Müslümanların sürgünü belirli oranda İspanya'nın ekonomik olarak gerilemesinin nedenleri arasinda görülürken, Kuzey Afrika'daki iktisadi dinamizmin de başlıca faktörlerinden biri olarak değerlendirilmektedir. Farkl ürünleri ve üretim tarzlarım Kuzey Afrika'ya taşıyan Endülüslü Müslümanlar bölgenin gelişmesine ciddi oranda katkı sağlamışlardır. Bu makalede Endülüs Müslümanlarnnın yerleştikleri bölgelerde sosyal ve ekonomik hayata yaptıkları katkılar ve bunların sonuçları tartışlacaktır.

\section{Abstract}

There are many studies on the exile of Spanish Jews from Spain and their settlement in Ottoman lands such as Istanbul, Selanik (Thessaloniki) and Izmir, and their effects on the broader Empire geography, however, there are limited number of studies regarding the social and economic consequences of the exile of Andalusian Muslims. The major waves of immigration that started after the surrender of Granada, the last Muslim city in the Iberian Peninsula, to the Spanish Kingdom in 1492, experienced the most severe period of immigration between 1609-1614 with the exile decision covering all remaining Muslims in the Peninsula in 1609. North African lands under the Ottoman rule were the primary regions where the exiled Muslims were settled. This exile had important consequences for both the Spaniards and the Ottomans. While the exile of Muslims is seen as one of the reasons for the economic decline of Spain to a certain extent, it is also considered as one of the main factors of the economic dynamism in North Africa. Andalusian Muslims, who carried various products and production styles to North Africa, contributed significantly to the development of the region. This article will discuss the contributions of Andalusian Muslims to the social and economic life in the regions where they settled and the results of those contributions. 


\section{GíRiş}

Osmanlı İmparatorluğu'nun kuruluşundan itibaren göçler ve sürgünler, iskân politikasının en önemli araçlarındandı. Devlet, kuruluşundan 20. yüzyıla kadar çeşitli nedenlerle yaşanan göçleri yönetmek ve buna dair politikalar geliştirmek için çaba içerisinde oldu. 16. yüzyılın başından itibaren politik olarak Osmanlı Devletini etkileyen önemli sosyal ve iktisadi hadiselerden biri de Endülüs Müslümanlarının İspanya'dan sürgünü olmuştur. II. Beyazıd'ın, Kemal Reis komutasındaki donanma ile dâhil olduğu bu süreç karadan ve denizden uzun süre devam etmiştir.

16. yüzyıl başlarında Osmanlı topraklarına sığınan Endülüs Müslümanları, kültürel seviyeleri, bilgi birikimleri, çalışkanlıkları ve girişimci özellikleri ile İberya Yarımadası'nda topluma katkıları yüksek düzeyde olan kesimi oluşturmaktaydılar. Sahip oldukları özellikler ile Hıristiyan toplumu kültür olarak etkilemekte ve iktisadi hayatı yönlendirmekteydiler. İberya Yarımadası'nın Hıristiyan krallıklar tarafından geri alınmasından sonra Endülüs Müslümanlarının büyük çoğunluğu Kuzey Afrika topraklarına, özellikle de Osmanlı hâkimiyetinde olan bölgelere göç etmeye başladılar. 1609 yılına gelindiğinde ise İspanya'da kalan ve Morisko olarak adlandırılan Müslümanların sürgününe karar verildi. Sürgün fikri bu kararın verildiği tarihten çok öncesine, 16.yüzyılın sonlarına dayanmaktaydı. Kararının gecikmesi, sürgünün yöntemine ilişkin tartışmalardan kaynaklanmaktaydı. Moriskolar potansiyel hain olarak görülmekte, İspanya'nın ve Hiristiyanlığın düşmanları kabul edilmekteydi (Abulafia, 2012, s. 533). Böylece 1609-1614 tarihleri arasında Endülüs Müslümanları İspanya'dan sürgün edildi.

Sürgün öncesinde Endülüs Müslümanları, Kastilya Kraliçesi İsabel ve Aragon Kralı Ferdinand'ın evliliklerinden sonra İberya Yarımadası'nın büyük bir kısmını hâkimiyeti altına alan bu iki krallığın toprakları başta olmak üzere Yarımadada yer alan diğer krallıklara dağılmış bir şekilde yaşamaktaydı. Aragon Krallığı 16. yüzyılın başında İspanyol Krallığı'nın bir parçası haline gelmişti. Aragon Krallığı, Aragon, Katalonya ve Valensiya bölgeleriyle birlikte Mayorka, Sardinya, Sicilya ve Napoli'den oluşmaktaydı. Aragon Krallığı içerisinde Morisko nüfusunun en yoğun olduğu yerler Aragon, Katalonya ve Valensiya bölgeleriydi. Üç bölge içerisinde ise asıl yoğunluk Valensiya'da toplanmaktaydı. Bu krallığa bağlı yerlerden olan Mayorka, Sicilya, Sardunya ve Napoli'de az miktarda Morisko bulunuyordu. Aragon'da yaşayan Moriskoların sayısının 250.000'i bulduğu tahmin edilmektedir. Bu rakam, 1.200.000'lik Aragon nüfusunun \%20'sini oluşturuyordu (Regla, 1963, s. 200). Aragon'da yaşayan Morisko nüfusunun çoğunluğu tarım sektöründe olmak üzere dönemin sanayi kollarında ve ticaret alanında faaliyet göstermekteydi (Colas Latorre, 2009, s. 190-191). Özellikle tarıma dayalı endüstriler olan ipekçilik ve şeker imalatı Moriskoların önemli faaliyet alanları arasında yer alıyorlardı (Epalza, 1992, s. 65-66).

İberya Yarımadası'nda yer alan krallıklar içerisinde en geniş toprağa sahip olan Kastilya Krallığı idi. Moriskolar bu geniş Kastilya topraklarında yer alan Eski Kastilya, Yeni Kastilya, Toledo, La Mancha, Extremadura, Endülüs ve Mursiye bölgelerinde yaşamaktaydılar. Kastilya Krallığında yaşayan Moriskoların nüfusu tahminlere göre 200-250 bin arasinda bulunmaktaydı (Epalza, 1992, s. 68). Kastilya ve Aragon 
krallıklarının haricinde Navarra Krallığı özellikle Tudela şehri, Portekiz, Balear Adaları (Mayorka Krallığına bağlıydı, sonrasında Aragon Krallığına katıldı), Kanarya Adaları Moriskoların yaşadığı yerler arasındaydı.

Endülüs Müslümanlarının İspanya'dan tamamen sürülmesine ilişkin tartışmalar II. Philip dönemine kadar gitmekteydi. Nitekim 1582 yılında II. Philip'e tüm Moriskoların sürgün edilmesini öneren bir teklif gitmişti. 17. yüzyılın başına gelindiğinde sürgün fikri iyice olgunlaşmış ve ağır basan bir düşünce olmuştu. Bu tarihlerde artık Moriskoların nasıl sürgün edileceklerine dair programlar hazırlanmaktaydı. 17. yüzyılın başlarında yaşanan siyasî ve iktisadî güçlükler de Moriskoların İspanya'dan çıkarılmasını savunanlar için müsait bir ortam hazırlamaktaydı. İspanya'nın Kuzey Avrupa'da Alçak Ülkeler olarak anılan bölgelerde devam eden savaşları, Batı Akdeniz'de devam eden mücadele ve kıyılarının güvenliğini sağlama çabası, bunlara bağlı olarak yapılan borçlanmalar neticesinde yaşanan 1596 ve 1607 iflasları, ülke içerisinde bir suçlu aranmasına yol açtı. III. Philip'in başbakanı el Duque de Lerma gibi önde gelen pek çok kimse, İspanya'nın temizlenmesinin yolunu Moriskoların sürgününde görüyordu. Sonuç olarak III. Philip, 9 Nisan 1609'da Moriskoların sürgün kararını verdi (Bal, 2011, s. 167). 1609-1614 tarihleri arasında gerçekleşen sürgün, yarım milyondan fazla insanı etkiledi (Özdemir, 2006, s. 217). Sürgün kararının temel nedenleri tamamen siyasi gözükmektedir. Sürgün, Krallığın varlığına karşı olabilecek tehlikeyi önlemeye dönüktü. İspanya'nın Moriskoların yardımı ile Müslümanlar tarafından işgal edileceği düşüncesi sürgün kararının alınmasında etkili olmuştu (Sanchez Blanco, 2009, s. 256-257). Alınan sürgün kararını haklı göstermek için yapılan siyasi propaganda çalışmaları, Moriskoların sürgününün İspanya'da Müslüman hâkimiyetini tam anlamı ile sonlandırdığı ve Reconquista tamamlandığı temeline dayaniyordu (Sanchez Blanco, 2009, s. 265).

Sürgünün demografik ve ekonomik etkileri ağırlıklı olarak Morisko nüfusunun çoğunluğunun yaşadığı Aragon Krallığı'nda görüldü. Moriskoların sürgünü sonrası büyük miktarda nüfus kaybı yaşayan Aragon issızlaştı. Nüfus kaybının ekonomik ve sosyal maliyetleri oldu. En büyük etki Aragon üzerinde olsa da krallığın tüm bölgelerine sürgünün zararlarından bir pay düştü. Sürgün tüm sektörleri etkiledi. Aragon sürgünün yol açtığı zararları bir yüz yıl boyunca saramadı (Colas Latorre, 2009, s. 208). Sürgün edilenlerin toplam sayısı ile ilgili çok farklı rakamlar zikredilmektedir. Henry Lapeyre'ye göre sürgün edilen Moriskoların sayısı 275 bin dolaylarındadır (Regla, 1963, s. 201). Regla ise Lapeyre'nin Kastilya ve Aragon için verdiği rakamların uyumsuz olduğunu söylemektedir. Ona göre sürgün edilen Moriskoların nüfusu 500 bin dolaylarında olmalıdır. Bunların 2/3'ü Aragon Krallığında, 1/3'ü ise Kastilya Krallığında yaşamaktaydı (Sanchez Blanco, 2009, s. 265). Bernard Vincent ise sürgün edilenlerin sayısının 300 binden aşağı olamayacağını, 350 bin dolaylarında olduğunu iddia etmektedir (Vincent, 2013, s. 27). Henry Charles Lea, dönem kaynaklarında sürgün edilenlerin sayısı ile ilgili iddia edilen rakamları bir araya getirmiştir (Lea, 2006, s. 345). Lea'nin verdiği rakamları özetleyecek olursak 
Guadalajara'ya ${ }^{1}$ göre sürgün edilenlerin sayısı 600 binin üzerindedir. Navarrete ise toplam 2 milyon Yahudi ve 3 milyon Moriskonun İspanya'dan sürüldüğünü söylemektedir. Navarrete bu görüşünü İspanya'nın, Moriskoların ve Yahudilerin sürgünü neticesinde 1ssızlaşması başlı̆̆ı altında söylemektedir (Navarrette, 1626, s. 50). Buradan onun sadece 1610-1614 sürgününü değil, Reconquista sonrası gerçekleşen bütün sürgün ve göçleri ifade ettiği anlaşılmaktadır. Yine Lea, Von der Hammer'in kürek cezası verilenler hariç sürgün edilenlerin sayısını 310 bin, Alfonso Sanchez'in ise 900 bin olarak telaffuz ettiğini söylemektedir. Llorante bir milyonluk bir tahminde bulunurken, Janer ise köleleştirilen ve ölen 100 bin kişiye ilave 900 bin kişinin sürgün edildiğini söylemektedir. Danvila y Collado ise yaptığı araştırmalar neticesinde 500 bin rakamına ulaşmaktadır. Danvila y Callado, kendisinden önce ve kendi asrında sürgün edilen Moriskolar ile ilgili sayıları paylaştıktan sonra resmi istatistikler üzerine yaptığı çalışmaya dayanarak sürgün edilenlerin sayısının 500 binin altında olamayacağını söylemektedir (Danvila y Callado, 1889, s. 339). Çalışmalara bütüncül olarak baktığımızda birbirinden farklı bu kadar çok rakamın olmasının bir nedeninin, sürgün edilenlerin sayısının tam olarak kayıt altına alınmamış olmasından kaynaklandığını görmekteyiz. Dolayısıyla 1609 ve 1614 yılları arasında tam olarak kaç kişinin sürgün edildiği bilinememekte ancak tahminler yapılmaya çalışılmaktadır. Rakamlar arasındaki farklılığın ikinci bir nedeni olarak ise sürgünün farklı zamanlarda gerçekleşmesi görünüyor. Her ne kadar 1609 yılında toplu sürgün kararı alınmış olsa da sürgün çok daha önce başlamış ve 1614 yılına kadar devam etmiştir, hatta azalarak da olsa bu tarihten sonra da devam ettiği söylenebilir.

\section{Endülüs Müslümanlarının Kuzey Afrika'da Yerleştikleri Yerler ve Osmanlı Yardımı}

Osmanlı Devleti'nin Endülüs Müslümanlarına yardımını arşiv belgelerine de yer vererek inceleyen bir çok çalışma yapılmış böylece konunun farklı boyutlarını ele alan önemli bir literatür oluşmuştur. ${ }^{2}$ Osmanlı Devleti'nin Endülüs Müslümanlarına yardımlarının başlangıcı 16. yüzyılın ilk dönemlerine kadar gitmektedir. 1505 yılında Kemal Reis bir Kısım Müslüman ve Yahudi'yi İspanya'dan kurtararak Osmanlı topraklarına getirmiştir (Özdemir, 2006, s. 223). Başta Barbaros Hayreddin Paşa olmak üzere Osmanlı denizcileri, İspanya kıyılarına seferler düzenleyerek bu bölgede yaşayan Endülüslülerin Kuzey Afrika topraklarına göçünü organize etmişlerdir. Barbaros Hayreddin Paşa, hatıralarında İspanya kıyılarına düzenlediği akınlardan ve Endülüs Müslümanlarını kurtarmasından bahsetmektedir (Düzdağ, 2004, s. 179). Endülüs Müslümanları da 1541 yılında Kanuni'ye yardım istemek için gönderdikleri bir mektupta, Barbaros'un kendilerine yaptığı yardımları ve 36 parçalık bir filo ile yedi

1 Marcos de Guadalajara y Javier'in (ö. 1630), Memorable Expulsion y justissimo Destierro de los Moriscos de España adlı eseri, ilk olarak sürgün tamamlanmadan önce, 1613 tarihinde basılmıştır. Bütün yönleri ile Moriskoların sürgünü konusunu ele almaktadır.

2 Endülüs Müslümanlarının Osmanlı Devletine göçü ve Endülüs Müslümanlarına Osmanlı yardımı hakkında ayrıntılı bilgi için bk. (Chakib, 1989; Şeyban, 2010; Özdemir, 2006; Bilgin, 2013a; Bilgin, 2013b; Kılıç, 2015). 
sefer yaparak 70.000 Müslüman'ı Kuzey Afrika'ya geçirerek kurtardığını söylemektedirler (Benafri, 1989, s. 53).

İnebahtı yenilgisi ve Kıbrıs'ın fethi gibi Osmanlı Devleti'nin o dönemdeki koşulları ve öncelikleri nedeniyle doğrudan İspanya'ya büyük bir donanma gönderilememekle birlikte Endülüs Müslümanlarına desteğe 16. yüzyıl boyunca devam edilmiştir. II. Selim (1566-1574) döneminde Endülüs Müslümanlarının yardım taleplerine verilen bir cevapta durumlarının farkında olunduğu, bununla birlikte donanmanın Kıbrıs'ın fethi ile meşgul olduğu, bu iş biter bitmez kendilerine yardım edileceği bildirilmekteydi (Özdemir, 2006, s. 225). Tunus ve Cezayir beylerbeyilerine gönderilen hükümlerle Endülüs muhacirlerine yardıma ve onların Osmanlı topraklarında iskânına devam edilmiştir. 1569 tarihli Cezayir Beylerbeyi Kılıç Ali Paşa'ya gönderilen hükümde, ayaklanan Müslümanlara yardım edebilmek için donanma göndermeye niyet edilmekle birlikte hacca giden Müslümanlara ve Müslüman tacirlere saldırıların merkezi haline gelen Kıbrıs'ın fethi ile uğraşıldığından bu donanmanın gönderilemeyeceği bildiriliyor. Ardından Kılıç Ali Paşa'ya, Endülüs Müslümanlarına her türlü yardımı yapması emrolunuyor. ${ }^{3}$ Bunun üzerine Kılıç Ali Paşa, 1569-1570 yılları arasında silah ve asker göndermek suretiyle orada ayaklanan Müslümanlara yardımda bulunmuştur. Aynı şekilde Endülüs Müslümanlarının yöneticilerine gönderilen hükümde de Müslüman hacı ve tacirlere yapılan saldırılar nedeniyle Kıbrıs'ın fethiyle meşgul olunduğu, Ada'nın fethinden sonra Endülüs'e donanma gönderilmesine karar verildiği açıklanmaktadır. Aynı belgede her ne kadar donanma gönderilemese de Cezayir Beylerbeyi'ne her türlü silah ve asker yardımını yapması için emir verildiği beyan edilmektedir. Gerek Cezayir beylerbeyilerine gerekse de Endülüs Müslümanlarının yöneticilerine gönderilen fermanlardan anlaşıldığına göre Osmanlılar öncelikle Doğu Akdeniz'i güvenlik altına almak istemekteydiler. Doğu Akdeniz, Uzakdoğu'dan gelen önemli ticaret yollarının birleşme noktasında yer alıyordu. Doğu Akdeniz limanlarında birleşen yollar buradan Akdeniz'in diğer limanlarına gitmekteydi. Aynı zamanda burası Osmanlı anakarasına en yakın bölge konumundaydı. Arap Yarımadası, Mısır ve Kuzey Afrika'ya giden yolların güvende olması, bu bölgenin kontrol altına alınmasına bağlıydı. Doğu Akdeniz'de Anadolu'ya yakın bir konumda olan Kıbrıs, o dönemde Venediklilerin elindeydi. Adanın Venediklilerin elinde olması, bu bölgede yapılacak ticari faaliyetlere ve başta askeri amaçlı olmak üzere gerçekleştirilecek diğer sevkiyatların güvenliğine zarar veriyordu. Dolayısı ile Osmanlılar öncelikle Kıbrıs Adasının fethini gerçekleştirerek Doğu Akdeniz' de tam anlamı ile hâkimiyet kurmak istemekteydiler.

17. yüzyılda, İspanya'dan sürgün edilen Endülüslü Müslümanların bir kısmı İstanbul başta olmak üzere Osmanlı topraklarına gelerek yerleştiler. İstanbul ve Anadolu'nun farklı bölgelerine yerleşen Endülüs Müslümanlarının sayılarının ne kadar olduğu bilinmemektedir. Fakat dönem tarihçilerinin verdiği bilgilerden çok sayıda Endülüslü Müslümanın Osmanlı topraklarına yerleştiği tahmin edilmektedir. Evliya Çelebi de Seyahatnâme'sinde I. Ahmet döneminde Endülüs'ten göç eden

3 II. Selim'in Endülüslülerin yardım isteğine verdiği cevap ve Kılıç Ali Paşa'ya gönderdiği hüküm hakkında detaylı bilgi için bk. (Chakib, 1989; Özdemir, 2006; Şeyban, 2010). 
Müslümanlardan bahsetmekte ve bunların Galata'da bulunan Müslüman mahallelerinde oturduklarını zikretmektedir (Evliya Çelebi, 1996, s. 183).

Endülüs Müslümanlarının Kuzey Afrika'da yerleştirildikleri şehirler ve nüfuslarının genel bir dökümünün henüz yapılmamış olması nedeni ile iskân süreçleri ve bununla ilgili geliştirilen politikalar hakkında yeterli bilgiye sahip değiliz. Ancak az sayıdaki arşiv belgesi, bunlara ilave olarak dönem tarihçi ve yazarlarının verdikleri bilgiler, ikincil literatür ile birlikte değerlendirildiğinde iskân süreçleri ve politikaları hakkında bir kanaat ortaya çıarmak mümkün görünmektedir. Zorunlu göçe tabi tutulan bir kısım Endülüslü Sale, Rabat ve Tetavin gibi Fas şehirlerine yerleşirken büyük çoğunluğu ise Osmanlı hâkimiyetinde bulunan Cezayir ve Tunus'a yerleşti. Endülüs Müslümanlarının bu bölgeleri tercih etmesinin en önemli sebebi, doğrudan Osmanlı kontrolünde olmayan bazı bölgelerde kendilerine kötü muamelede bulunulması, mallarının yağmalanması ve canlarına kastedilmesiydi. İspanyollarla ittifakları nedeniyle bazı küçük krallıkların Endülüslü Müslümanları kabul etmemeleri de onların Osmanlı hâkimiyetinde olan bölgeleri tercih etmelerinin nedenleri arasında sayılabilir. Kuzey Afrika'ya göç eden muhacirler özellikle Türklerin kontrolünde olan bölgeleri tercih etmekteydiler. ${ }^{4}$

17. yüzyılın önde gelen hadis ve tarih âlimlerinden olan Makkari (ö. 1632), Endülüs Müslümanlarının tarihi, hicretleri, hicret sonrasında yerleştikleri yerler ve hicret yolculuklarında karşılaştıkları muameleler hakkında bilgi veren önemli bir kaynaktır. Onun Nefhü't-Tib adlı eserinde Endülüslü Müslümanların göçleri ile ilgili kayıtları ilgi çekicidir:

1017 yılında (M. 1609) Hıristiyanlar Müslümanları ihraç edince onlardan binlercesi Fas'a, binlercesi de Vahran'da Tilimsan'a yerleştiler. Çoğunluğu ise Tunus'a gittiler. Yollarda onlara bedeviler ve Allah'tan korkmayan kimseler tasallut etti, malların yağmaladı. Bu hadiseler Tilimsan ve Fas'ta oldu. Bu ezadan çok az bir kısmı kurtulabildi. Tunus taraflarına gidenlerin ise çoğunluğu emniyet içerisinde oldu. Bu dönemde onlar buranın boş köy ve şehirlerini imar ettiler. Aynı şekilde Tetavin, Sale ve Cezayir'de Mitice'ye de yerleştiler. El-Magribu'l-Aksa sultanı bunlardan asker istihdam etmeye başlayınca Sale'ye yerleştiler. Bunlarm içerisinde günümüzde de meşhur olduğu gibi denizde cihad edenler vardı. Sale kalesini güçlendirdiler, orada saraylar, evler, hamamlar bina ettiler. Onlar bugün de aynı şekilde durmaktadır. Onlardan bir kısmı Büyük Konstantiniyye'ye, Mısır'a, Şam'a ve farklı İslam diyarlarına yerleştiler (Makkari, 1968, C. 4, s. 528).

Endülüslü muhacirlerin yerleştiği bölgelerin başında gelen Cezayir, Kuzey Afrika'daki en büyük Müslüman nüfusu barındırıyordu. Cezayir'in coğrafi olarak İspanya'ya yakınlığı ve Osmanlı Devleti'nin batı sınırını oluşturması, İspanya ile bu bölge arasındaki savaşları ve İspanya'dan sürülen Müslümanların burayı tercih etme nedenini açıklamaktadır. Dönem Cezayir'i için merkezi bir siyasi otoritenin

4 İspanyollar, Kuzey Afrika'da bulunan krallıklarla yaptıkları anlaşmalara Endülüs Muhacirlerini ülkelerine kabul etmeme şartını koymaktaydılar. Bu konuda daha ayrıntılı bilgi için bk. (Bal, 2011). 
varlı̆̆ından söz etmek güçtür. Merkezi otoritenin etkisi başkent Cezayir şehrinde, Osmanlı askeri garnizonlarının bulunduğu liman şehirlerinde ve doğu-batı doğrultusunda uzanmakta olup yine Osmanlı garnizonlarını bulunduğu Tilimsan (Tremecen), Mediye, Msile, Konstantiniye gibi şehirlerde kendini göstermekteydi (Epalza, 1992, s. 207).

1609-1614 sürgünü öncesinde ve sürgünde Cezayir'e göç eden Endülüs Müslümanları, doğrudan Osmanlı kontrolünde olan şehirlere ve şehirlerin çevresinde yer alan kırsal bölgelere yerleştiler. Zira Makkari'nin de işaret ettiği gibi, Osmanlı kontrolü dışında kalan bölgelerde mallarına ve canlarına zarar gelmesi gibi olumsuz koşullarla karşılaşma ihtimalleri bulunmaktaydı. Endülüs Müslümanlarının Cezayir'de yerleştiği başlıca şehirler Cezayir, Tilimsan, Mediye, Msile, Konstantiniye gibi doğu-batı istikametinde iç bağlantı yollarının üzerinde bulunan Osmanlı askeri garnizonlarının bulunduğu yerlerdir.

Endülüslü muhacirler, Cezayir şehri çevresinde genelde şehre yakın kırsal bölgelerde, Mitice Nehri'nin vadilerinde yerleşmiş durumdaydılar. Bu yerler arasında günümüz şehirlerinden Buleyde (al-Buliada) ve Kolea (al-Kulai'a) yer almaktadır. Bu iki şehir askeri garnizonlar olup burada Osmanlı kaleleri bulunmaktaydı (Saiduni, 1981, s. 118). Şerşâl ve Birchik (Birşek) de Endülüslü muhacirlerin Cezayir'de yerleştiği önemli şehirlerdendir. Kitabu'l-Bahriye'de Piri Reis de bu iki şehrin nüfusunun önemli bir kısmını Endülüslü Müslümanların oluşturduğundan bahsetmektedir (Piri Reis, 2002, 478). Nüfusunun önemli bir kısmını daha önceden kaybetmiş olan Birchik, göç ile gelen Endülüslülerin buraya yerleşmesi ile yeniden imar olunmuştur (Saiduni, 1981, s. 118). Şerşâl, Endülüslü muhacirlerin gelmesiyle büyümüştür ve buradaki evlerin büyük çoğunluğunun sahibi Endülüslü muhacirler olmuştur. Endülüslülerin Şerşâl'deki evlerinin sayısı 12 bini bulmaktaydı (Saiduni, 1981, s. 117).

Cezayir'e yerleşen Endülüslü Müslümanlar çok hızlı bir şekilde yönetici kesimden Türklerle kaynaşmak suretiyle onların en büyük destekçileri oldular. Bu kaynaşmada yönetici kesimi oluşturan Türkler ile Endülüs muhaciri kadınların yaptı̆̆ evliliklerin rolünün de olduğu düşünülebilir. Nitekim oraya giden Osmanlı idareci ve askerleri içerisinde yerli halktan ve Endülüs'ten göç eden Müslüman kadınlarla evlilik yapanlar bulunmaktaydı (Kavas, 2001, s. 35). Endülüs muhacirleri genel itibari ile kırsal kesimde ziraatla uğraşan kimselerle şehirli esnaf ve sanatkâr kısmını oluşturmaktaydı. Muhacirlerin bir kısmı da büyük tüccar ve toprak sahibi grup içerisinde yer almaktaydı. Büyük toprak sahibi ve tüccar arasında kendilerinin Hz. Peygamber'in soyundan geldiğini söyleyen Şerifler de bulunmaktaydı. Kırsal kesimde yaşayan Endülüslüler, Cezayir'de bulunan Osmanlı askeri garnizonlarının bulunduğu şehirlerde toplumun diğer kesimleriyle karışık bir biçimde yaşıyorlardı (Epalza, 1992, s. 209).

Endülüs muhacirlerinin Kuzey Afrika'da yerleştiği ikinci yer Tunus olmuştur. Tunus'a Endülüs Müslümanlarının yoğun olarak yerleşimi 1609 sürgünü ve sonrasında başlamıştır (Bilgin, 2013, s. 36). Buraya geç yerleşmeye başlamalarının sebebi, Tunus'un 1574 yllından itibaren tam olarak Osmanlı hâkimiyetine girmesidir. Tunus'a yerleşen Endülüs Muhacirlerinin genelini Aragon, bir kısmını ise Valenciya ve 
Kastilya'dan gelenler oluşturmaktaydı. İçlerinde âlimler, idareciler, eşraftan kimseler, farklı meslek gruplarından zanaatkârlar ve çiftçiler bulunmaktaydı. Bunlar, mesleklerine göre iskâna tabi tutulmuşlardı (Şeyban, 2010, s. 345). Buradan Osmanlıların diğer bölgelerde uyguladığı iskân politikalarının benzerini Kuzey Afrika' da da uyguladığı sonucunu çıkartmak mümkündür. Kişilerin mesleklerine göre şehirlerde veya kırsal kesimde yerleştirilmesi Osmanlı iskân politikasının önemli bir parçasını oluşturmaktaydı. Tunus'a yerleşen Endülüs Müslümanları Osmanlı ordusunda ve bürokrasisinde önemli görevler üstlenmişlerdir. Endülüs Müslümanlarının Tunus'ta yerleştikleri iki önemli şehir Tunus ve Bizerta'dır. Şehirlerin haricinde kırsal kesime yerleşen Endülüs Müslümanları buralarda köy ve kasabalar oluşturmuşlardır. Medjerda Nehri vadilerinde, Tunus şehri çevresinde, Tunus ve Bizerta şehirleri arasındaki ovalarda, Tunus ve Nabil şehirleri arasındaki ovalarda ve Zağvan'da kasaba ve köyler kurmuşlardır (Epalza, 1992, s. 269). Endülüslülerin Tunus'ta kurduğu bu kasabalar şehir yapısı ve mimari özellikler bakımından tamamen Endülüs tarzını yansıtmaktaydı. Bunlardan en önemlisi Testur (Testour) kasabasıdır. Testur, Medjerda Vadisi'nin, Grombalia'nın ve diğer Endülüs kasabalarının ticari merkeziydi (Epalza, 1992, s. 269). 17. yüzyılın önde gelen Tunuslu âlimlerinden İbn Ebû Dinar'a göre Testur (Testour), Tunus'ta Endülüslü muhacirlerin yaşadığ1 en önemli şehirlerden olmuştur. Dönemin idarecisi Osman Dayı'nın destekleri ile buraya yerleşen Endülüslüler şehri üzüm bağları, zeytinlikler ve bahçelerle donatmışlar ve buranın yerlisi olarak görülmeye başlanmışlardır (İbn Ebu Dinar, 1993, s. 228).

\section{Endülüs Müslümanlarının Sosyal ve Ekonomik Hayata Etkileri}

Osmanlı topraklarına yerleşen Endülüslü Müslümanlar, başta tarım ve sanayi olmak üzere pek çok alanda sahip oldukları bilgi ve tecrübe ile ekonomiye müspet yönde katkıda bulunmuşlardır. Tunus ve Cezayir gibi Endülüs Müslümanlarının kitleler halinde yerleştikleri bölgelerde bu katkı daha bariz gözlemlenebilmektedir. Endülüslülerin yerleştikleri alanların genel olarak eski yerleşim yerleri veya yeterli nüfusa sahip olmayan bölgeler olduğu göz önünde bulundurulduğunda, buraların şenlendirilmesi ve inşasında önemli bir rol üstlendikleri görülmektedir. Kuzey Afrika'da daha çok kıyı bölgelerine yerleşen Endülüs Müslümanları, şehirlerin çevresinde yer alan Mitice, Şerşâl (Cherchel), Tilimsan ve Annabe gibi ovalarda yaptıkları ıslah çalışmaları ile buraları verimli tarım alanlarına dönüştürmüşlerdir. Mitice Ovası ve Cezayir şehrinin yakınlarında yer alan yüksek alanlar, Valensiya ve Aragonlu çiftçilerin çalışmaları neticesinde bağlar ve bahçelerle dolmuştur. Kiraz, armut, elma, portakal, zeytin, incir ve üzüm; Endülüs Müslümanlarının gelmesiyle Cezayir'in önemli ürünleri arasına girmiştir. Geleneksel ipekçilik sanatlarını devam ettiren Endülüslüler, dut yetiştiriciliğine hassasiyet göstermişler, pirinç ve pamuk ziraatının yaygınlık kazanmasına öncülük etmişlerdir (Saiduni, 1984, s. 140). Özellikle Annabe bölgesi zeytinciliğin merkezi haline gelmişti. $\mathrm{Bu}$ bölgede Endülüs muhacirlerinden sadece Mustafa Kardenas'a ait 30 binin üzerinde zeytin ağacı vardı ve ziraattan elde ettiği servetini Endülüslü Müslüman esirlerin kurtarılması için fidye olarak kullanmaktaydı (Saiduni, 1981, s. 119). Bu dönemde Amerika Kıtası kökenli olan 
misır ve domates gibi bitkiler de bölgede yetiştirilmeye başlanmıştır (Bilgin, 2013, s. 38). Endülüs Müslümanlarının topluma olan katkısı, bölge halkı tarafından da takdir edilmiştir. Endülüslülerin hicretinden sonra Tunuslu bir şairin sözleri bunu açıça ifade etmektedir:

"Sizinle ihya olur yerleştiğiniz her yer, siz susuz araziye düşen yağmur gibisiniz. İnsanlar sizde ancak güzellikler görür, çünkü siz insanların başındaki göz gibisiniz." (Şeyban, 2010, 347).

Akdeniz coğrafyası genel itibari ile yazları kurak ve sıcak bir iklime sahip olup kış ayları yağışlı geçer. Kışın zaman zaman sellere sebebiyet veren yağışları geçtiğinde yaz mevsiminin kavurucu sıcakları her yeri adeta çöle dönüştürür. Bu nedenle Akdeniz coğrafyasında tarımdan verim alabilmenin yolu, yağışların bol olduğu mevsimde suları tutup yağışların az olduğu veya olmadığı mevsimlerde kullanabilme kabiliyetine bağlıdır. Endülüs Müslümanları bu konuda büyük bir tecrübeye sahiptiler. Yaptıkları barajlar, açık ve kapalı su kanalları, nauralar (su değirmeni), su kuyuları ve su dolaplarıyla İberya Yarımadası'nda neredeyse ekilmedik yer bırakmamışlardı. ${ }^{5}$ Endülüslü muhacirler, su teknolojileri ve sulamalı tarımla ilgili tecrübe ve birikimlerini göç ettikleri yerlere de aktardılar. Yerleştikleri bölgelerde setler, açık ve kapalı su kanalları, açık ve kapalı sarnıçlar ve nauralar inşa ettiler. Böylece bu bölgelerde sulamalı tarım yapabildiler. Buraları sebze ve meyve bahçeleriyle donattılar. Cezayir'de Endülüslü muhacirlerin yerleştiği önemli bölgelerden olan Tenes, Şerşâl (Cherchel), Kolea ovaları; kiraz, elma, üzüm, portakal, limon ve dut yetiştiriciliğinin yaygın olarak yapıldığı bölgeler haline geldi.

Endülüslü Müslümanların Cezayir tarımına sağladıkları katkılar bir Endülüs şehri olan Buleyde'de (Buleyde) çok daha rahat gözlenmektedir. 16. yüzyıldan itibaren bölgeye yerleşmeye başlayan Endülüslüler, şehrin etrafında yer alan Mitice Ovası'nı 1slah ederek bağcilık faaliyetlerinde bulundular ve narenciye başta olmak üzere birçok ürünün yetiştirilmesine öncülük ettiler. Bu bölgeyi Barbaros Hayreddin Paşa, Sidi Ahmed el-Kebir'in maiyetindeki Endülüslü Müslümanlara ikta olarak vermişti. Bölgeye yerleşen Müslümanlar, inşa ettikleri su kanalları vasıtası ile geniş bir alanın sulanmasını sağlayarak sebze ve meyve yetiştiriciliğine önem verdiler (Saiduni, 2003, s. 31). Endülüs Müslümanları Buleyde'ye, hamam, fırın ve cami inşa ettiler. Bu cami, Saiduni'nin haber verdiğine göre günümüzde de varlığını devam ettirmekte ve Türk Camii olarak bilinmektedir (Saiduni, 1981, s. 31). Makkari de Mitice'yi Endülüs'ten sürülen Müslümanların en önemli yerleşim yerlerinden olarak zikretmektedir (Makkari, 1968, C. 4, s. 528). 18. yüzyılın başlarında Kuzey Afrika'ya, Hıristiyan kölelere hizmet edecek bir hastane kurma fikri ile giden ve Mayıs 1719'da, Buleyde'yi ziyaret eden Rahip Francisco Ximenez Buleyde'yi şöyle tasvir etmektedir:

"Illk bakışta insanı dinlendiren meyve ağaçları ve yabani ağaçlarla dolu bahçeler son derece zevkli bir şekilde düzenlenmişti... Zengin Moriskoların evleri çok etkileyiciydi... Yol kenarında Moriskolarm çok fazla tükettiği leben (ayran) denilen ekşi sütü satan

5 Endülüs'te su teknolojileri ile ilgili olarak daha geniş bilgi için bk (Bal, 2012). 
insanlarn görüntüleri resmedilmeye değer birer tablo gibiydi..." (Queslati, 1986, s. 171).

Ximenez, şehrin surlarını ve evlerini tasvir ediyor ve onların "İspanyol tarzında çatılarla kaplı çok güzel evler olduğunu, bu evlerin İspanya'dan sürülen Moriskolar tarafindan yapıldığııı" söylüyor. Ximenez'i şehrin meyve ağaçlarıyla, özellikle de portakal, limon, elma ve üzüm bağlarıyla dolu bahçeleri etkilemiştir (Queslati, 1986, s. 172).

Endülüslü muhacirlerin Cezayir'de olduğu gibi Tunus tarımına da önemli katkıları olmuştur. Osmanlı hâkimiyeti öncesi uzun süre savaşlar nedeni ile harap olmuş, nüfusu seyrelmiş Tunus'a Osmanlı hâkimiyeti ile istikrara kavuşması sonrasında göç ile gelen Endülüslü çiftçiler, tarım alanında atılım yaşatmıştır. Sulama sistemlerini yenilemişler, meyve ağaçları dikmişler, özellikle bahçecilik ve bağcılıkta Tunus'un ilerlemesine katkı sağlamışlardır. İspanya'da ziraatı ile uğraştıkları zeytinciliği ve portakal yetiştiriciliğini burada da sürdürmüşlerdir (Yassine Bahri, 2009, s. 271). 1720 yılının Eylül Ayında Bizerta'yı ziyaret eden Ximenez, şehrin zengin tarımı ile ilgili aşağıdaki bilgileri veriyor:

Bu ülke pek çok çeşit ă̆açlar, meyve ve sebzelerle dolu bahçelere sahip. Üzüm bağlar bulunmakta, buğday, arpa, pamuk, mısır ve diğer tohumlu bitkilerin ziraatı yapılmaktadır. Bu topraklarda çavdar ekildiğini görmedim. Üzümcülü̈̆̈̈n ve zeytinciliğin İspanya'dan gelen Moriskolar tarafindan yapıldiğg söyleniyor. Üzüm bağlar ve zeytinliklerin Endülüs tarzında olmasından bunun kesinlikle doğru olduğu anlaşılıyor. Zeytin türlerinin çoğu Sevilla zeytinleri ile aynı cinstendir. İspanya'dan gelen Moriskolar sayesinde Afrika'nın ve Berberistan'ın başka yerlerinde böylesine iyi ziraat yapılan başka arazi bulunmamaktadır. Moriskolar bugün de İspanyolcalarını korumaktalar ve yaşlılar İspanyolcayı düzgün telaffuz etmektedirler (Epalza, 1984, s. 216).

Endülüslülerin su teknolojileri alanında Osmanlı hâkimiyetindeki Kuzey Afrika'nın, şehir ve kır hayatına önemli katkıları olmuştur. Su teknolojileri hakkında bilgi birikimine ve tecrübeye sahip olan Endülüslü muhacirler, bu alandaki maharetlerini yerleştikleri yeni yerlerde de kanıtlamışlardır. Kurdukları su gücü ile çalışan değirmenleri hem sulamada hem de başka amaçlar için kullanmışlardır. Su kanalları, kemerler, sarnıçlar ve benzeri su sistemlerini kullanmak suretiyle Cezayir ve Tunus'ta bulundukları bölgeleri canlandırmışlardır. 17 ve 18. yüzyıllarda Cezayir'e giden Avrupalı seyyahlar bu konu ile ilgili gözlemlerini eserlerinde paylaşmaktadırlar. Endülüslü muhacirlerin yaptığı en önemli sulama sistemlerinin başında Usta Musa'nın, Köse Mustafa Paşa (1610-1613) döneminde Cezayir şehrine yaptığ $4500 \mathrm{~m}$. uzunluğundaki su kanalı gelir. Yine Buleyde'de (Buleyde) Endülüslü muhacirler tarafından Sidi Ahmed el-Kebir Vadisi olarak bilinen vadinin sularını toplayan ve sulama amaçlı kullanılan $1500 \mathrm{~m}$. uzunluğunda bir su kanalı yapılmıştır. Bunlardan başka Kolea, Şerşâl vb. birçok şehirde Endülüslü muhacirler su kanalları yaparak, kuyular açarak sulama sistemleri kurmuşlardır (Saiduni, 2003, s. 51).

Endülüs Müslümanları, muhtelif sanayi dallarında da faaliyet göstermekteydiler. Debbağlık, ayakkabıcılık, demircilik, silah ve barut imalatı, ipekli ve yünlü 
dokumacılık, terzilik, eczacılık, çömlekçilik, ayakkabıcılık, doğramacılık gibi birçok zanaat, uğraşı alanları arasında yer alıyordu. 16. yüzyılın ikinci yarısında bilhassa Cezayir şehri hakkında geniş bilgi veren kaynaklardan olan Diego de Haedo'ya ait Topografía e historia general de Argel isimli eserde Cezayir şehrinin yerli halkı dört gruba ayrılmakta ve dördüncü grup olarak Granada, Aragon, Valensiya ve Katalonya'dan göç ederek gelen Endülüs muhacirleri zikredilmektedir. Eserde, Endülüslü muhacirlerin tamamının bir zanaat bildiği ve her birinin farklı zanaatla meşgul olduğu anlatılmaktadır. Haedo, içlerinde arkebüzcüler, barutçular, demirciler, marangozlar, duvar ustaları, terziler, ayakkabıcılar, kuyumcular, ipekçiler ve eczacılar bulunan Endülüs muhacirlerinin yerli halktan ayrı olarak Türkler gibi giyindiklerini söylemektedir (Heado, 1927, s. 50-51).

İpekçilik, Endülüslü muhacirler için önemli bir sanayi dalıydı. Dokudukları ipekli kumaşlar, iç ve dış pazarlarda rağbet görmekteydi (Saiduni, 1984, 141). İpekçilik 14. yüzyıldan itibaren Granada' dan Cezayir'in batı kıyılarında yer alan şehirlerine, buraya göç eden muhacirler tarafından taşındı (Epalza, 1992, s. 253). Endülüs muhacirlerinin önemli sanat dallarından biri de kadife kumaş dokumacılığıydı. Granada muhacirleri, kadife kumaş dokumacılığında uzmandı. Dantel ve işlemecilik, Endülüslü kadınların en önemli sanatları arasında yer alıyordu (Saiduni, 1984, 141). Halı dokumacılığı da Endülüslülerin önemli sanatları arasındaydı. Endülüs tarzı halı dokumacılığı Cezayir'de Endülüslü muhacirler tarafından yaygınlaştırıldı (Saiduni, 1981, 120). Sabun imalatı, ıtriyat ve ilaç yapımı Endülüslü muhacirlerin meşgul olduğu zanaatlar arasındaydı. Başta gül olmak üzere farklı bitkilerin çiçeklerinden, narenciye ve portakal çiçeklerinden parfüm yapılmakta, bunların suları gıdalarda da kullanılmaktaydı (Saiduni, 2003, 54). Sabun, Endülüslü muhacirlerin yerel piyasalar kadar ihracat için de imal ettiği ürünler arasında bulunuyordu. Endülüslüler tarafından üretilen sabunlar, yine Endülüs kökenli tacirler tarafından Akdeniz ülkelerine ihraç edilmekteydi (Villanueva Zubizarreta, 2013, s. 377).

Kuzey Afrika'da çok eski dönemlerden itibaren yapılmakla birlikte Endülüs Müslümanlarının daha da geliştirdiği bir sanat da şaşiye adı verilen, daha çok kırmızı ve siyah renklerde olan başlıkların (fes) imalatıydı. Önceleri Endülüs'te de yaygın olarak kullanılmakta olup Toledo Başlığı olarak anılan fesin Kuzey Afrika'da imalatı ve ticareti Endülüs Müslümanlarının tekelindeydi. Cezayir şehrinde şaşiye çarşısı bulunuyordu (Saiduni, 1984, 141). Tunus'ta da şaşiye imalatı Endülüslülerin tekelinde idi. Şaşiye imalatında 17. yüzyıl Avrupa'sında da yaygın olarak kullanılan putting-out (evlere iş verme) sistemine benzer bir organizasyon modeli kullanılmaktaydı. Ham olarak tacire gelen yünler imalat için evlere ve atölyelere gönderiliyor, imalat tamamlandiktan sonra tekrar tacire geri geliyordu. Hammadde olarak yünün alınmasından, imalatın tamamlanmasına ve ardından iç ve dış piyasalara ürünün sürülmesinde tamamen Endülüslüler çalışıyordu. Bu da Endülüslülerin şaşiye imalat ve ticaretinde tekeli ellerinde bulundurmalarına imkân sağlamaktaydı (Villanueva Zubizarreta, 2013, s. 378). Endülüslülerin Kuzey Afrika'ya yerleşmeye başlaması ile birlikte şaşiye imalatı en canlı dönemini yaşamaya başlamıştır. Araştırmalar, bölgenin en önemli ihraç ürünü haline gelen şaşiye sektörünün üretiminden satışına kadar 
muhtelif aşamalarında 15 bin ile 80 bin arasında kişi çalıştığına işaret etmektedir (Gafsi Slama, 1997-1998, s. 224).

Endülüs tarzı çömlekçilik, Kuzey Afrika'ya Endülüs muhacirleri tarafından getirilmiş bir sanat dalıdır. Çömlekçiler Endülüs tarz ve desenlerinde ürettikleri tabak, vazo, sürahi gibi ev eşyalarının yanı sıra çok daha geniş ölçekte ticareti yapılan seramik imalatı da yapmaktaydılar. Tunus'ta Endülüslüler tarafından imalatı yapılan seramikler Fransa, İspanya, İtalya ve Hollanda gibi dış ülkelere ve Osmanlı Devletinin farklı eyaletlerine ihraç edilmekteydi (Villanueva Zubizarreta, 2013, s. 379).

Endülüs muhacirleri, gemi inşası ve denizcilikte maharetleri ile Cezayir'de Osmanlıların İspanya kıyılarına yaptıkları baskınlarda en önemli dayanakları arasında bulunuyorlardı. Haedo, Moriskoların gemi inşa faaliyetlerinin her aşamasında çalıştıklarını belirterek (Haedo, 1927, s. 81). Osmanlı donanması için ne derece önemli olduklarına işaret etmektedir. Özellikle Şerşâl nüfusunun büyük kısmını oluşturan Endülüslü Müslümanlar, burada brigantin adı verilen süratli ve küçük gemilerin inşasını yapıyorlardı. İnşa ettikleri bu küçük ve hızlı gemilerle sürekli İspanya kıyılarına baskın vermekteydiler. Endülüs muhaciri denizciler, İspanya kıyılarını çok iyi tanımaları, hemen her yerinde önceden tanıdıkları Morisko dostlarının olması ve iyi İspanyolca konuşmaları nedeniyle bu baskınlarda İspanya kıyılarına en büyük zararı vermekteydiler (Haedo, 1927, s. 91-92). Osmanlı denizcilerinin İspanyol kıyılarına karşı yaptıkları başarılı faaliyetlerin arkasında Endülüslü muhacirlerin payı önemlidir. İspanya kıyılarını iyi bilen Endülüslü muhacirler, Osmanlı denizcilerine rehberlik yapıyorlardı. Birçok Endülüslü gemi reisi olmuştu. Kaynaklarda Endülüslü muhacirlerin içerisinden çıkan meşhur denizcilerin arasında Blanquillo (Blanko) Reis, Ahmet Ebu Ali Reis, Büyük Murad Reis, Cevad Yanu Reis'in isimleri zikredilmektedir (İnan, 1987, s. 388).

Endülüs Müslümanlarının yerleştikleri yerlerde Endülüs mimarisi dikkat çekmekteydi. Evler, camiler, saraylar gibi pek çok yapı Endülüs geleneksel mimarisinin izlerini taşımakta idi. Cezayir ve Tunus şehirlerinde Endülüs mimarisinin izlerini her zaman görmek mümkündür. Endülüslülerin yoğun bir şekilde yerleştiği ve tarihi özelliklerini bugün dahi korumakta olan Tunus'un Testur (Testour) şehri Endülüs mimarisinin en güzel örneklerini yansıtmaktadır. Medjerda Nehrinin kıyısına kurulan şehrin, nehre uzanan üç ana caddesi bulunmaktaydı. Şehir, yerleşimcilerin iskân süresince zamanla kurulan Endülüs, Tagarinos ve el-Hara olmak üzere üç mahalleden oluşuyordu (Villanueva Zubizarreta, 2013, s. 382). Şehre, 1610 yıllarında gelerek yerleşen ilk muhacirler, buranın ilk mahallesini kurmuşlar ve ilk camiini inşa etmişlerdi. Daha sonra Endülüs muhacirlerin gelmeye devam etmesi ile Tagarinos Mahallesi kuruldu. Buraya şehrin Ulu Camii de inşa edildi. Sonraki yıllarda Yahudilerin yerleşmesi ile el-Hara Mahallesi de ortaya çıtı (Villanueva Zubizarreta, 2013, s. 383). Şehrin merkezinde bulunan meydanda çarşı, hamam, ulu cami, medreseler ve zaviye bulunmaktadır. Testur (Testour) evleri, Toledo evleri ile aynı mimari özellikleri taşımaktadır. Testur'un (Testour) Ulu Camii ve minaresi Burgos ve Toledo mimarisini andırmakta ve bir Endülüslünün elinden çıktığını hemen belli 
etmektedir (Ravillard, 1981, s. 620). 1720 yılında şehri ziyaret eden Francisco Ximenez şehir hakkında detaylı bilgiler vermektedir:

Burası, Medjerda Nehrinin yakınında bulunan bir ovaya kurulmuştur. Burayı İspanya'dan göç eden Moriskolar çok eski dönemlerden kalma harabelerin üzerine kurmuşlardır. Şehre, Arapça'da izin müsaade anlamına gelen Textor (Testour) ismi verilmiştir: Muhtemelen Endülüslüler kendilerine buraya iskân izni verilmesi nedeni ile bu adı vermişlerdir. Granada'ya benzer bir şekilde inşa edilmek istenmiştir. Bir mahallesi Alhambra diye adlandirnlmakta ve diğerleri de Granada'daki gibi isimlendirilmektedir (Epalza, 1984, s. 219).

Şehrin ortasında dört köşeli olarak meydan yer almaktadır. Moriskolar burada İspanya'da olduğu gibi boğa güreşleri yapmaktadırlar. Şehirde 800 ev bulunmakta olup her biri İspanya'da olduğu gibi çatıl ve avluludur. Bunlardan bazılarn Morisko stilinin aksine balkonlu ve pencerelidir. 6 cami, dokuz ribat ve bir zaviye bulunmaktadır. Çeşme bulunmamaktadır... Yönetimi Endülüslü Moriskolar tarafından yapılmaktadır. Yönetimde İspanya'da olduğu gibi Moriskolardan bir şeyh, iki kadı ve bir de güvenlikten sorumlu kişi bulunmaktadır. Endülüslü bu Moriskoların içerisinde çok sayıda Tagarino ve Aragonlu bulunmakla birlikte çoğunluğu, koşulların gereği, evlilik yolu ile karışma sonucu Araplaşmıştır. Çocuklar İspanyolcayı artık kaybetmektedirler. Sadece yaşlı Endülüslüler iyi ve akıcı İspanyolca konuşmaktadırlar (Epalza, 1984, s. 219).

Endülüs muhacirleri, iç ve dış ticarette başarılıydılar. Endülüslülerin dış ticarette başarılarında Akdeniz'in farklı bölgelerindeki yine Endülüs kökenli tacirlerle olan irtibatları etkiliydi. Başta Venedik, Livorno gibi ticaret şehirlerindeki Endülüs asıllı Yahudilerle kurdukları ticari ilişkiler olmak üzere farklı şehirlerdeki Endülüs kökenli tacirlerle bağları sayesinde Akdeniz ticaretinde yer edinmişlerdi (Epalza, 1992, s. 140). Endülüs muhacirleri arasında köle ticareti de yaygındı. Hıristiyan esirleri satın alarak kölelikten kurtarmak için Cezayir'e gelen pek çok rahip, Moriskoların köle ticareti ile uğraştıklarından bahsetmektedir.

Endülüslülerin Cezayir ve Tunus'ta Osmanlı toplumuna katkıları sadece ticariiktisadi faaliyetleriyle olmamış, bunun yanı sıra başta Endülüs'ten göç edenler olmak üzere toplumun ihtiyaç sahibi kesimlerini desteklemeye yönelik içtimai faaliyetlerde de bulunmuşlardır. Camiler, medreseler ve diğer hayır kurumlarını inşa etmişler ve bunları destekleyecek vakıfları kurmuşlardır. Gerek Cezayir'de gerekse de Tunus'ta Endülüslü erkek ve kadınlarca kurulmuş birçok vakıf bulunmaktadır. Osmanlı dönemi Cezayir şehrinde Endülüs göçmeni Müslümanlara ait vakıflar, dördüncü sırada yer almaktaydı. Saiduni'nin ifadesine göre 19. yüzyılda Cezayir'de Endülüs muhacirlerinin vakıflarına ait ev, tarla, fırın ve benzeri toplam 101 gayrimenkulden yıllık yaklaşık 5000 Fransız Frangı gelir elde ediliyordu (Saiduni, 2003, s. 90). Bu vakıflara bazı örnekler zikredilebilir. Örneğin Ben Nikroun ailesinden Seyyide Meryem, kendi adına bir cami inşa ettirmiş ve bu caminin ihtiyaçlarına yönelik olarak 3 ev ve 14 dükkânı vakfetmiştir (Chakib, 1989, s. 143). Yine Endülüs göçmenlerinden Ali Tevlid el-Endülüsi, Miliana şehrinde bir evi ve bahçeyi; Mediye'da mukim olan 
Morisko Hasan Hoca iki ev ve bir çömlek atölyesini Harameyn için vakfetmiştir. Buleyde'de zanaat ile meşgul olan bir grup Endülüs göçmeni ise Haremeyn için şasiye yapılmak üzere bir mekânı vakfetmişlerdir. Abdurrahman b. Ahmed el-Endülüsi isimli bir şahıs bir hanı ve hanın haricinde bir dükkânı Harameyn fakirlerine vakfetmiştir. Hacı Muhammed el-Endülüsi, Cazayir şehrinin ulu camii "el-Camiu'l-Azzam" için ev ve işyeri vakfetmiştir (Saiduni, 2003, s. 91).

Endülüs muhacirleri, özellikle de 1609-1614 sürgünü sonrası önemli sayıya ulaşmaları nedeniyle, Cezayir ve Tunus'ta sosyal yapının önemli bir unsuru durumundaydılar. Gerek Avrupalı seyyahların gözlemleri gerekse de arşiv belgeleri, Endülüslülerin Tunus ve Cezayir'de önemli bir sosyal sınıf oluşturduklarını ortaya koyuyor. Endülüslüler, tarım ve zanaatlarda çok aktif olup servet elde etmede başarılıydılar. Kuzey Afrika'da Osmanlı topraklarına yerleşen Endülüs Müslümanları kısa bir sürede topluma adapte olmuşlar ve aynı zamanda yönetici sınıfı oluşturan Türklerle işbirliğine girmişlerdi. Şehirlerde yaşayan Endülüslüler genel itibari ile küçük esnaf sınıfına girmekle birlikte içlerinde yüksek gelir sahibi olanlar da vardı. Kırsal kesimde yaşayanlar ise özellikle tarım alanındaki başarıları ile hemen sivrilmekteydiler. Endülüs Müslümanlarının Kuzey Afrika ortamına hızla adapte olarak zenginliğe kavuşmalarında onların Akdeniz'in farklı şehirleri ile ticari bağlantılar kurma kapasitelerinin rolü vardır. Bu ticari bağlantılarında farklı bölgelere yerleşmiş bulunan Endülüslülerin katkısı önemli olmuştur. Fas, Cezayir, Tunus, Trablus, İstanbul, Selanik, İzmir ve İskenderiye gibi şehirlerle bağları, onların ticari alanda başarılı olmalarına yardımcı olmuştur.

Endülüs muhacirlerinin Tunus ve Cezayir'de topluma uyumlarında Osmanlı Devleti'nin verdiği destek de gözden uzak tutulmamalıdır. Yerli halkla ve yerel idareciler ile karşı karşıya kaldıklarında şikâyetlerini Padişah'a iletmişler ve her zaman destek almışlardır. 1573 tarihli bir belgede fakir Endülüslü muhacirlerin, Padişah'a bir kişiyi göndererek mal ve mülklerini terk edip Cezayir ve oraya tabi yerlere gelmeleri nedeniyle yoksul düşmelerine rağmen oranın yöneticilerinin diğer reayadan alındığı gibi kendilerinden de rüsum ve bazı tekâlif istediklerinden şikâyet ettikleri görülmektedir. Aynı belgede ırgatlık ve rençberlik ile elde ettikleri akçelerinin ellerinden alındığından, hatta bazı gemicilerin kıyafetleri dahil bütün mallarına el koyduklarından şikayet etmektedirler. Bunun üzerine bölge yöneticilerine gönderilen hükümde, irgatlık ve rençberlik ederek geçimini sağlayanların akçesini alanlardan ve mal-mülklerine el koyanlardan bunların geri alınarak kendilerine iade edilmesi istenmiştir. Ayrıca Endülüs muhacirlerinin üç yıl süre ile her türlü vergiden muaf olmalarına, üç yıl sonra her biri iktisadi bakımdan güçlenince kendilerinden diğer reayadan alınan rüsum, hukuk ve tekâlifin alınmasına hükmedilmiştir (BOA, A.DVNSMHM.00023.00072, h. 224).

Endülüs muhacirlerinden ilim ehli olan bazı kimseler kadılık ve benzeri idari görevlere gelmek istediklerinde yerli halkla aralarında rekabetten kaynaklı sorunlar ortaya çıkması üzerine Hilafet makamına yazıp destek istemişlerdir. Nitekim 1573 yılında Padişah'a yaptıkları müracaatta kendilerine cihet verilmediği, dışardan gelmeleri sebebiyle ayrım yapıldığı konusunda şikâyette bulunmuşlardır. Bunun 
üzerine Padişah, Cezayir Kadısına ferman göndererek İspanya'dan gelen Endülüslü ilim adamları ve diğerlerine ayrım yapılmaksızın vazife verilmesini ferman buyurmuştur (BOA, A.DVNSMHM.00023.00063, h. 244). Tunus Beylerbeyi'ne yazılan h. 1022 (1613/1614) tarihli bir hükümde ise dinlerine olan bağlılıkları nedeniyle İspanya'dan sürgün edilmeleri nedeniyle Osmanlı topraklarına gelen muhacirler konu edinilmektedir. Hüküm, İspanya muhacirlerine ziraatla meşgul olabilmeleri için Adana, Uzeyr, Misis, Trablusşam ve Kars sancaklarından bazı bölgelerin yurt olarak ayrıldığını ve bunların beş sene müddetince vergiden muaf tutulduklarını belirtmektedir. Beş sene sonra ise ödeyecekleri verginin, Padişah'ın yaptırdığı caminin vakfına verileceği ifade olunmaktadır. Belgede muhacirlerden Tunus'ta kalmak isteyenlere engel olunmaması ve kendi rizasıyla gelmek isteyenlerin getirilmesi emir olunmaktadir (BOA, A.DVN.MHM.d 078, h. 441). Kuzey Afrika'da bulunan Osmanlı idarecileri ve toplum önderlerinin, payitahttan gelen fermanlar doğrultusunda, Endülüs Müslümanlarının topluma adaptasyonunda her türlü kolaylığı sağlamaya çabaladıkları anlaşılmaktadır. Bunlardan biri olan Osman Dayı, Tunus'a Endülüs Muhacirlerinin yerleşmesini teşvik etmekle ve merkezi hükümetin bildirdiği vergi muafiyetlerini sağlamakla yetinmemiş, onlara güvenlikleri için silah, ziraat yapabilmeleri için toprak ve toprağı ekecekleri tohumu dağıtmak gibi birçok yardımda bulunmuştur (Bahri, 2009, s. 268). Tunus'un o dönem sözü geçen âlimlerinden olan Ebu'l-Gays el-Kaşşaş, Tunus halkını evlerini göçmenlere açmaya teşvik etmiştir. Ebu'lGays'ın da teşvikleriyle birçok insan Endülüslü Muhacirleri bağırlarına basarak onlar yardım etmiştir (Bahri, 2009, s. 269). Ebu'l-Gays el-Kaşşaş, muhacirlerin ilk geldiği günden itibaren onların gıda ve giyinme gibi öncelikli ihtiyaçlarının karşılanmasıyla birlikte ilk etapta ikamet edebilecekleri mekânların belirlemesine odaklanmıştır. Muhacirlere, bir yıl boyunca günlük olarak 1200 buğday ekmeği, iki kafîz (yaklaşık 66 litre) buğday, iki kafîz kuskusluk buğday, süt ve et gibi gıdaların dağıtımını sağlamıştır (Epalza, 1999-2002, s. 151). Ebu'l-Gays, Endülüslü Muhacirlerin yerleşimini ve adaptasyonunu kolaylaştırmak için onlarla yakından ilgilenmiştir. Göçün ortaya çıkardığı sosyal gerginlikleri önleme adına yerel idareciler ve muhacirler arasında köprü olmuştur. Muhacirlerin temel ihtiyaçlarının karşılanmasında, zaviyeler gibi geçici konaklama yerlerinde kalmalarında, ardından kalıcı yerleşim yerlerine kavuşmalarında büyük çaba sarf etmiştir (Villanueva Zubizarreta, 2013, s. 370).

\section{SONUÇ}

Endülüs Müslümanlarının sürgünü, İspanya'da sosyal ve ekonomik yapıyı derinden etkiledi. Sürgün, pek çok araştırmacı tarafından, İspanya'nın 17. yüzyılın başından itibaren iktisadi gerileyişinin temel nedenlerinden biri olarak görüldü. Müslümanların sürgünü, İspanya'nın Valensiya, Granada gibi şehirleri başta olmak üzere Akdeniz kesiminde yer alan bölgelerinde tarım ve endüstri faaliyetlerinin uzun yıllar sürecek bir gerileme içerisine girmesine neden oldu. Müslümanların sürülmesi başta şeker kamışı, pirinç ve tahıl olmak üzere ziraî üretime ağır bir darbe indirdi. Sürgün, tarımın dışında ipekçilik, dericilik gibi Endülüs Müslümanları tarafından yürütülen sanayi sektörlerinin ve bir takım ticarî faaliyetlerin de gerilemesine yol açtı. 
Endülüslü muhacirlerin Osmanlı topraklarında etkisinin hissedildiği en önemli bölge Kuzey Afrika coğrafyası olmuştur. Kuzey Afrika'nın yerli halkları Berberiler, Araplar ve sonrasında Türklerin katılımı ile çok kültürlü bir yapıda olan bölgeye Endülüs muhacirlerinin gelmesi sosyal yapıyı daha da zenginleştirdi. Yeni bir kültürün taşıyıcısı olan Endülüslüler, yerleştikleri yerlerde iktisadi hayatı etkileyerek bölgenin ekonomik gelişiminde ve toplumun refahının artışında önemli bir rol üstlendiler. Kuzey Afrika'da bilinen üretim tekniklerini öğrenip geliştirmekle kalmadılar, yeni üretim tekniklerini, tarımda ve zanaatlarda sahip oldukları tecrübe ve bilgi birikimini yeni yurtlarına taşıdılar. Farklı bölgelere göç eden Endülüslü diğer muhacirler ile irtibatları, Batı dillerine ve kültürlerine hâkimiyetleri ile bölgesel ve uluslararası ticarette aktif olarak yer aldılar. Yerleştikleri kasaba ve şehirlerin canlı birer üretim ve kültür merkezi olmasını sağladılar. Aynı zamanda siyasi ve askeri alanda da faaliyette bulundular. Yönetici kesimi oluşturan Türkler ile kurdukları yakın ilişki sayesinde idareye katkı sağladılar. Osmanlı denizcileri ile birlikte Akdeniz'de korsanlık faaliyetlerine katıldılar. İspanyolca bilmeleri ve İspanya kıyılarına hâkimiyetleri sayesinde buralara pek çok başarılı akınların yapılmasına öncülük ettiler.

İspanya'dan sürgün edilen Endülüs Müslümanlarının Kuzey Afrika' da yerleştikleri bölgelere hılı uyumlarında; kültürel, sosyal ve iktisadi hayata katkı sağlamalarında Osmanlı yönetiminin destekleyici tavrı etkili olmuştur. Osmanlı Devleti, hâkimiyeti altında bulundurduğu coğrafyalarda uyguladığı nüfus ve iskân politikalarının benzerini Kuzey Afrika'da da uygulamıştır. Din ayrımı gözetmeksizin kabul ettiği göçmen nüfusu kabiliyetlerine uygun bir şekilde iskâna tabi tutmuştur. Muhacirlerden esnaf ve zanaatkârları şehirlere yerleştirirken tarımla uğraşanlarını kırsal alanlara yerleştirerek buraların şenlenmesini sağlamıştır. Bu nedenle Endülüslü muhacirler Kuzey Afrika'da, Osmanlı hâkimiyetinde olan yerlerin dışında maruz kaldıkları zorluklarla karşılaşmamışlar, çok daha hızlı bir şekilde topluma uyum sağlamışlardır.

Endülüs'ten göç etmek zorunda kalan Müslümanlar, yerleştikleri Osmanlı bölgelerinde kısa sürede topluma adapte olmuşlar ve üretken sınıfın arasındaki yerlerini almışlardır. Endülüslü muhacirlerin toplumsal uyumunda ilk olarak göçle geldikleri toplum ile kültürel bağlara sahip olmaları gelmektedir. Her ne kadar İberya Yarımadası'nın Hıristiyan krallıklar tarafından geri alınması aşamasında, özellikle de 1492 yılında Granada'nın teslimi ile birlikte başlayan süreçte, oradaki Müslüman topluma yapılan baskı, din değiştirme ve İslam dünyası ile iletişimlerini koparma çabaları etkisini göstermiş olsa da aradaki bağlar hiçbir zaman tam olarak sonlanmamıştır. Bu da göç eden Müslümanların yeni geldikleri yerlere özellikle de Kuzey Afrika'ya adaptasyonlarını kolaylaştırmıştır. Endülüslü muhacirlerin yerleştikleri bölgelere uyumunda ikinci neden olarak sahip oldukları nitelikler gelmektedir. Endülüslü Müslümanlar, kırsal kesimde çiftçilikle, şehirlerde ise zanaat ve ticaret ile uğraşmakta olup geçmişe dayanan bilgi ve birikimleri ile İspanya'nın nitelikli insan kaynağını oluşturmaktaydılar. Ziraatta ve zanaatlarda sahip oldukları niteliklerini, göç ile geldikleri yeni yurtlarında topluma katkı olarak sunmuşlardır. Böylece yerleştikleri bölgelerde üretime katılmışlar, ölü arazilerin ihya faaliyetini gerçekleştirmişler, kaybolmaya yüz tutmuş şehirleri canlandırmışlar, sosyal ve iktisadi 
refahın gelişmesine katkı sağlamışlardır. $\mathrm{Bu}$ da onların toplumsal kabullerini sağlamıştır. Endülüslü muhacirlerin ticari faaliyetlerde başarısında farklı bölgelere yerleşen diğer Endülüslü göçmenlerle ilişkilerini devam ettirmelerinin etkisi olmuştur. Bu sayede kurdukları bağlar yardımıyla bölgesel ve uluslararası ticarette başarılı olmuşlardır. Ticari faaliyetlerdeki başarıları da zirai ve sınai üretim faaliyetlerinin gelişmesine katkı yapmıştır. Endülüs Müslümanlarının yerleştikleri bölgelere uyumlarında ve iktisadi başarılarında bir başka etken ise Osmanlı Devleti'nin kendilerine sahip çıkması, onları koruması ve başarılı oldukları alanda teşvik etmesi olmuştur. Endülüslü muhacirlere göç sürecinde yardım edilmekle yetinilmemiş, yerleştikleri Kuzey Afrika topraklarında da ziraatle uğraşanlara toprak verilmiş, esnaf sınıfından olanlarına iş sahibi olma imkânı tanınmış, idari süreçlerde ve ilmiye sınıfında görev yapabilecek olanlarından bu çerçevede yararlanılmıştır. Ayrıca kendilerine belirli bir süre vergi muafiyeti sağlanmak suretiyle iktisadi bakımdan güçlerini artırmalarına ve toplumun üretken kesimi arasında yer almalarına imkân tanınmıştır. Böylece Endülüs'ten Kuzey Afrika'ya göç etmek zorunda bırakılan Müslümanlar, kısa sürede yeni geldikleri bölgelere adapte olmuşlardır. Göç ile geldikleri topluma girişimcilikleri ile iktisadi anlamda katkı sağlamakla kalmamışlar, kurdukları vakıflar ile hem iktisadi katkıya devam etmişler hem de sosyal alana katkı sağlamışlardır. Nitekim Endülüslülerin kurdukları vakıflar, bizatihi Endülüs muhacirlerinin ihtiyaçlarını karşılamaya dönük olduğu gibi aynı zamanda cami, medrese gibi kurumların yapılmasına, harameyne hizmet edilmesine ve hacca gidenlere yardım edilmesine yönelik vakıflar olmuştur.

\section{EXTENDED ABSTRACT}

One of the important social and economic events that politically affected the Ottoman Empire since the beginning of the 16th century was the exile of Andalusian Muslims from Spain. Andalusian Muslims who took refuge in Ottoman lands made significant contributions to Spanish social and economic life with their cultural level, knowledge, hard work and entrepreneurial characteristics. The recapture of the Iberian Peninsula by the Christian kingdoms fueled the migration process of Andalusian Muslims from the Peninsula. In 1609, it was decided to exile all Muslims left in Spain who were called Morisco. Before the exile, Andalusian Muslims were living in several kingdoms of the Peninsula, Castile and Aragon kingdoms being the ones that hosted a large number of Moriscos. The region with the highest population of Morisco was the Kingdom of Aragon, which became a part of the Spanish Kingdom at the beginning of the 16th century. It is estimated that there was a Morisco population of around 250,000 within the Kingdom of Aragon. This figure made up 20\% of the Aragon population of 1,200,000. An estimated 200,000 to 250,000 Moriscos lived in the Kingdom of Castile, which has the largest land among the kingdoms on the Iberian Peninsula. Apart from those two kingdoms, the Kingdom of Navarra, Portugal, the Balearic Islands and the Canary Islands were among the places where Moriscos lived. On April 9, 1609, during the reign of III. Philip, the ruling of exiling of Moriscos was made. The exile that took place between 1609 and 1614 affected more than half a million people. It also deeply affected the social and economic structure in Spain and has been considered by many 
researchers as one of the main reasons for Spain's economic decline that began at the beginning of the 17 th century.

The history of the Ottoman Empire's assistance to the Andalusian Muslims goes back to the early 16th century. Many studies have been carried out examining the Ottoman support to Andalusian Muslims by including archive documents, thus important literature has been formed that deals with different aspects of the subject. In the 17th century, while some of the Andalusian immigrants exiled from Spain settled in different parts of Istanbul, the Balkans and Anatolia, most of them settled in the provinces under the Ottoman rule in North Africa. Since an inventory on the cities where Andalusian Muslims were settled in North Africa and of their population has not been made yet, we do not have sufficient information about the settlement processes and the policies developed in this regard. However, when the few archive documents, in addition to the information provided by the historians and writers of the period, are evaluated together with the help of secondary literature, it seems possible to come up with an opinion about the settlement processes and policies. Most of the Andalusians who were subjected to forced migration settled in Algeria and Tunisia, which were under Ottoman rule. The most important reason why Andalusian Muslims preferred these regions was that they were mistreated, looted of they faced dangers for their properties and lives in some regions that were not directly under Ottoman control.

Algeria, one of the regions where those immigrants settled, hosted the largest Andalusian Muslim population in North Africa. The main cities where Andalusian Muslims settled in Algeria are the places home to Ottoman military garrisons such as Algeria, Tilimsan, Mediye, Msile and Konstantiniye. Tunisia was the second place where Andalusian immigrants settled in the region. The settlement of a large number of Andalusian Muslims in the country started in 1609. Most of the Andalusian immigrants who settled in Tunisia were from the Kingdom of Aragon while some of them came from Valencia and Castile. There were scholars, administrators, notables, artisans from different professions and farmers among them. These were settled according to their profession. Thus, it is possible to conclude that the Ottomans applied the settlement policies similar to the settlement policies applied in other regions in North Africa. The settlement of people in cities or rural areas per their professions was an important part of the Ottoman settlement policy. Two important cities where Andalusian Muslims have settled in Tunisia are Tunisia and Bizerta.

Andalusian Muslims who settled in the Ottoman lands contributed to the development of the economy of the region with their knowledge and experience in many fields, especially in agriculture and industry. Considering that the areas where Andalusians were settled in Tunisia and Algeria are generally old settlements or regions that did not home to a large number of inhabitants, it is seen that they play an important role in the construction of these places. Andalusian Muslims transformed the plains such as Mitice, Şerşâl (Cherchel), Tilimsan and Annabe into fertile agricultural lands with their rehabilitation works. Andalusian immigrants transferred their previous experience and knowledge of water technologies and irrigated 
agriculture to the places they migrated. They have made those plains suitable for irrigated agriculture. Andalusian immigrants, who made a breakthrough in agriculture in their settlements, renewed their irrigation systems, planted fruit trees, and contributed to the progress of the region, especially in horticulture and viticulture.

Andalusian Muslims were also active in various branches of industry. Tanner, shoemaking, ironworking, gun and gunpowder manufacturing, silk and wool weaving, tailoring, pharmacy, pottery, and joinery were among the fields of professions they were involved. Sericulture was an important branch of industry for Andalusian immigrants. The silk fabrics they weaved were in demand in domestic and foreign markets. One of the important branches of the art of Andalusian immigrants was velvet fabric weaving. Granada immigrants were experts in weaving velvet fabrics. Carpet weaving was also among the prominent arts of Andalusians. Andalusian style carpet weaving was popularized in Algeria by those immigrants. Soap manufacturing, perfumery, and medicine making were among the crafts majorly owned by Andalusian immigrants. Although it has been made in North Africa since ancient times, another art developed by Andalusian Muslims was the manufacture of headdresses (fes), which were mostly in red and black colours, called Şaşiya. The Andalusian Muslims dominated the manufacturing and trade of the şaşiya in North Africa. An organizational model similar to the putting-out system, which was widely used in 17th century Europe, was opted in the manufacture of the şaşiya. The wool, which came to the merchant as raw material, was sent to the houses and workshops for manufacturing, and after the production was completed, it was returned to the merchant. From purchasing wool as raw material to completing the manufacturing and then launching the product to the domestic and foreign markets, the Andalusians were in control entirely. Andalusian style pottery is a branch of art brought to North Africa by the Iberian Peninsula's immigrants, as well. Meanwhile, the Andalusian immigrants were among the most important pillars of the Ottoman navy in Algeria and Tunisia with their skills in shipbuilding and maritime. Andalusian architecture drew attention to the places where they settled. Many buildings such as houses, mosques and palaces bear the traces of traditional Andalusian architecture. Andalusian immigrants were successful in domestic and foreign trade. The connections of them with the merchants of Andalusian origin in different regions of the Mediterranean have been effective in their success in foreign trade. Besides, the contribution of Andalusians to the Ottoman society in Algeria and Tunisia was not only through commercial-economic activities but also in social activities. They built mosques, madrasas and other charities and established foundations to support them. There are many foundations established by Andalusian men and women in Algeria and Tunisia.

Muslims, who had to emigrate from Andalusia, quickly adapted to society in the Ottoman regions where they settled and took their places among the productive class. The first thing in the social harmony of Andalusian immigrants is that they have cultural ties with the society they migrated to. Andalusians have never been completely severed with the rest of the Islamic world. This facilitated the adaptation of immigrant Muslims to their new settlement areas. The second reason for the 


\section{5ELÇUKTÜRKIYAT}

immigrants to adapt to the regions they settled in is the qualities they have. Andalusian Muslims were dealing with farming in rural areas and crafts and trade in cities and had knowledge and experience benefiting from their past. They have presented their qualifications in agriculture and crafts as a contribution to the society in their new home countries. They took part in the production in the regions they settled in, carried out the activities of reviving the plane lands, revitalized the cities, and contributed to the development of social and economic prosperity. This facilitated their social acceptance. Another factor in the adaptation of Andalusian Muslims to the regions they settled in and their economic success was the Ottoman Empire's owning and protecting them. Andalusian immigrants were not only assisted during the immigration process, but those engaged in agriculture, for example, were also given land in where they settled in the North African territories, the tradesmen were allowed to carry out their businesses, and those who could work in the administrative processes and the ilmiya class were presented with an opportunity in those fields. Besides, they were given the opportunity to increase their economic power as they were provided with a tax exemption for a certain period of time. Thus, Muslims, who were forced to migrate from Andalusia to North Africa, adapted to their new regions in a short time. They not only contributed to society with their entrepreneurship but also continued to contribute to the economy with the foundations they established. 


\section{KAYNAKÇA}

BOA. A.DVNSMHM.00078.00222. Hüküm 441.

BOA. A.DVNSMHM.00023.00072. Hüküm 224.

BOA. A.DVNSMHM.00023.00063. Hüküm 244.

Abulafia, D. (2012). Büyük deniz Akdeniz'de insanlık tarihi (G. Ç. Güven, Çev.). İstanbul: Alfa Basim.

Bahri, R. Y. (2009). Aportes Culturales de Los Moriscos en Tunez. Revista de Historia Moderna, 27, 265-275.

Bal, F. (2011). Osmanlı Devleti - İspanya iktisadi ilişkileri (16.-18. yüzyıllar) (Yayınlanmamış Doktora Tezi). Marmara Üniversitesi, İstanbul.

Benafri, C. (1989). Endülüs'te son Müslüman kalıntısı Morisko'ların Cezayir'e göçü ve Osmanlı yardımı (1492-1614) (Yayımlanmamış Yüksek Lisans Tezi). Hacettepe Üniversitesi, Ankara.

Bilgin, F. (2013). Osmanlı hâkimiyetindeki Tunus'a Endülüs Müslümanlarının (MüdeccenlerMoriskolar) göçleri (XVI.-XVII. Asırlar). Akademik İncelemeler Dergisi, 18 (1), 37-61.

Colas Latorre, G. (2009). Los Moriscos en Aragon. Moliner Prada, A. (Ed.), La Expulsion de los Moriscos içinde (s. 179-209) Barcelona: Nabla Ediciones.

Danvila y Collado, M. (1889). La Expulsión de los Moriscos Españoles. Madrid: Librería de Fernando Fé.

Düzdağ, M. E. (2004). Kaptan-ı Derya Barbaros Hayrettin Paşa'nın hatıraları (2. bs.). İstanbul: Işık Yayınları.

Epalza, M. (1984). Nuevos Documentos Sobre Descendientes de Moriscos en Tunez en el Siglo XVIII. Studia historica et philologica in honorem M. Batllori, Roma: Instituto Español de Cultura, 195-228.

Epalza, M. (1992). Los Moriscos Antes y Despues De La Expulsion. Madrid: Editorial Mapfre.

Epalza, M. (1999-2002). Sidi Bulgayz, protector de los moriscos exiliados en Túnez (s. XVII). Nuevos documentos traducidos y estudiados" Sharq al-Andalus, 16-17. 141-172.

Evliya Çelebi. (1996). Seyahatnâmesi 1. Kitap: İstanbul. Orhan Ş. G. (Haz.), İstanbul: Yapı Kredi Yayınları.

Fernandez de Navarrete, P. (1626). Conservacion de Monarquias Discursos politiquos. Madrid: La imprenta real.

Gafsi Slama, A. (1997-1998). La Familia Lakhoua, Descendientes Tunecinos de Moriscos Granadinos de los Siglos XVII-XVIII, y sus Actividades en la Industria del Bonete Chechía. Sharq Al-Andalus, 14-15. 219-244.

Hanefi, H. (2014). el-Kadiyyetu'l-Muriskiyye fi'l-Fedai'l-Cezayiri'l-Usmaniyyi ala dui'lFermanati'l-Usmaniyye (1492-1614). el-Hivaru'l-Mutevassiti, 1, 9-37.

Heado, D. (1927). Topografía e historia general de Argel. Madrid: Imp. de Ramona Velasco.

İbn Ebû Dinar, Ebu Abdullah Muhammed b. Ebü'l-Kasım er-Ruayni (1993). Mu'nis fì ahbari Ifrikıyye ve Tunis. Beyrut: Dârü'l-Mesire.

İnan, M. A. (1987). Nihayetü'l-Endelüs ve Tarihu'l-Arabi'l-Mutenassırin. Kahire: Mektebetü'lHanci.

Kavas, A. (2001). "Kuzey Afrika'da Bir Osmanlı Nesli: Kuloğulları”, Osmanlı Araştırmaları, 21, 31-68.

Lea, H. C. (2006). İspanya Müslümanları Hristiyanlaştırlmaları ve sürülmeleri. (A. Davudoğlu, Çev.). İstanbul: İnkılab Basım Yayım.

Makkari, Ebü'l-Abbas Şehabeddin Ahmed b. Muhammed b. Ahmed (1968). Nefhü'tTtib min Gusni'l-Endelüsi'r-Ratib. Beyrut: Dâru Sadır. 
Oueslati, H. (1986). Argel, Segun El Diario Inedito De Francisco Ximenez (1718-1720). Sharq alAndalus, 3, 169-181.

Özdemir, M. (2006). Endülüs Müslümanları 1. Ankara: Türkiye Diyanet Vakfı Yayınları.

Piri Reis (2002). Kitabı Bahriye. Ankara: T. C. Başbakanlık Denizcilik Müsteşarlığı Araştırma, Planlama ve Koordinasyon Dairesi Başkanlığı.

Ravillard, M. (1981). Los moriscos en Berbería. Nueva Revista de Filología Hispánica, 30 (2), 617629.

Regla, J. (1963). La expulsión de los moriscos y sus consecuencias en la ecomomía valenciana. Hispania: Revista española de historia, 4, 200-218.

Saidunî, N. (1981). el-Caliyetu'l-Endulusiyye bi'l-Cezairi Müsahemetuhe'l-imraniyye ve neşatuhe'l-ïktisadi ve vaduhe'l-İçtimai. Avrak 4, 111-124.

Saidunî, N. (1984). Dirasat ve Ebhas fì Tarihi'l-Cezair: el-Ahdü'l-Osmani. Cezayir: el-Müessesetü'lVataniyye li'l-Kitâb.

Saidunî, N. (2003). Dirasat'ün-Endelüsiyye: Mezahirü't-Te'siri'l-İberi ve'l-Vücudi'l-Endelüsi bi'lCezair. Beyrut: Darü'l-Garbi'l-İslami..

Sanchez Blanco, R. B.(2009). Los Moriscos en la Politica de la Monarquia Hispanica y su expulsion. Antonio M. P. (Ed.), La Expulsion de los Moriscos içinde (235-266). Barcelona: Nabla Ediciones.

Şeyban, L. (2010). Mudejares ve sefarades: Endülüslü Müslüman ve Yahudilerin Osmanlı'ya göçleri. İstanbul: İz Yayıncilı.

Villanueva Zubizarreta, O. (2013). Los Moriscos en Tunez. Mercedes G. A. ve Gerard W. (Ed.). Los Moriscos y Diaspora Una Perspectiva Internacional içinde (362-390). València: Universitat de València.

Vincent, B. (2013). La geografia de la expulsion de los Moriscos: Estudio cuantitativo. Mercedes G. A. ve Gerard W. (Ed.). Los Moriscos y Diaspora Una Perspectiva Internacional içinde (2744). València: Universitat de València. 